\title{
KAJIAN DESKRIPTIF PEMANFAATAN INTERNET OLEH MAHASISWA DI JURUSAN TEKNIK OTOMOTIF FAKULTAS TEKNIK UNIVERSITAS NEGERI PADANG PADA TAHUN 2012
}

Oleh :

\author{
Dwi Sudarno Putra ${ }^{1)}$, M Nasir ${ }^{2)}$ \& Irma Yulia Basri ${ }^{3)}$ \\ 1) Jurusan Teknik Otomotif UNP (e-mail : dwisudarnoputra@gmail.com) \\ 2) Jurusan Teknik Otomotif UNP (e-mail : mhd.nasir.92@facebook.com) \\ 3) Jurusan Teknik Otomotif UNP (e-mail : irma_yulia_77@yahoo.com)
}

\begin{abstract}
This research is aim to describe how student use the internet in campus Automotive Engineering Department Padang State University at 2012. Descriptive Research Method was used for this research. Questionnaire was made to obtain the data. Its Questions are about the knowledge of internet facilities and use of the Internet by college students on campus. Questionnaire distributed to 138 respondents. From questionnaire data founded that $84 \%$ respondents using campus wifi hotspot for more than two days a week. About 99\% of them use the internet to seek learning material to improve academic and technical knowledge. But, unfortunately Academic Information System are still not fully utilized. For example, only 9 of the respondents who have used discussion / chat online as one of a services of Academic Information System.
\end{abstract}

Keywords : Descriptive research, utilization of the Internet, Students, Academic Information System Utilization.

\section{PENDAHULUAN}

Dunia pendidikan semakin berkembang dari tahun ke tahun. Kebutuhan dalam kehidupan menjadikan perubahan dunia pendidikan melibatkan banyak aspek, diantaranya penggunaan teknologi internet. Mulai dari Sekolah Dasar, Sekolah Menengah Pertama (SMP), Sekolah Menengah Atas (SMA) maupun Perguruan Tinggi semuanya melibatkan teknologi internet dalam kegiatan pendidikannya. Pendidikan pada jenjang perguruan tinggi dirasakan paling banyak melibatkan unsur teknologi internet, karena cakupan pendidikannya lebih luas dan lebih kompleks sehingga memerlukan teknologi yang bisa memudahkan dalam semua proses dalam aktivitas pendidikannya.

Teknologi internet dalam pendidikan perguruan tinggi biasanya diaplikasikan untuk proses administrasi dan perkuliahan. Diantaranya mencakup pendaftaran dan penerimaan mahasiswa baru, pengumuman dan pemberitaan kampus, sarana komunikasi antara mahasiswa dengan dosen dan mahasiswa dengan mahasiswa, mengunduh berkas nilai, melihat Lembar Hasil Studi (LHS) hingga menyusun Kartu Rencana Studi (KRS) online. Seluruh layanan tersebut biasanya disediakan oleh kampus pada situs resmi yang telah dikembangkan. Penggunaan internet dalam dunia pendidikan memang bukanlah suatu hal baru, terlebih jika melihat perkembangan 
teknologi modern yang sangat pesat, sehingga perlu ada penyesuaian antara dunia pendidikan dan perkembangan di masa depan.

Infrastruktur Internet di UNP

$$
\text { 2012, jurusan Teknik Otomotif }
$$
Universitas Negeri Padang telah memiliki total 5 hotspot wifi, tiga hotspot wifi untuk mahasiswa dan dua hotspot wifi untuk dosen, semuanya dapat berfungsi dengan baik. Jumlah infrastruktur hotspot wifi di jurusan Teknik Otomotif cukup memadai untuk mendukung aktivitas internet mahasiswa dan dosen.

Sistem Informasi di UNP dan Pemanfaatannya

Di Universitas Negeri Padang, penggunaan internet untuk pelayanan mahasiswa, sepeti pendaftaran mahahasiswa baru yang secara resmi dimulai pada tahun 2009. Hal ini dilakukan untuk memudahkan pengelolaan data pendaftaran calon mahasiswa tersebut. Untuk saat ini, penggunaan internet tidak lagi terbatas pada pelayanan mahasiswa baru, hampir semua keperluan administrasi kampus dapat dilakukan via internet, misalnya pengambilan mata kuliah, melihat info terbaru kampus ataupun melakukan pemilihan umum ketua BEM. Layanan yang paling banyak digunakan pada situs resmi kampus adalah portal akademik, penggunaanya biasanya untuk melihat Lembar Hasil Studi (LHS) dan mengisi Kartu Rencana Studi (KRS). Situs resmi kampus terbagi menjadi beberapa sub bagian, bagian paling terkecil adalah pada tingkat fakultas, sedangkan untuk tingkat jurusan masih belum ada untuk saat ini.

Tingkat mobilitas mahasiswa
berbeda-beda, khususnya untuk
mahasiswa tingkat akhir yang banyak
melakukan kegiatan di luar kampus
seperti PLI dan PLK yang terkadang

malah ditempatkan diluar daerah. Untuk mengantisipasi adanya masalah yang ditimbulkan hal tersebut, maka jurusan Teknik Otomotif membutuhkan situs resmi jurusan yang memberikan pelayanan secara online seperti pengumuman, pengunduhan berkas administrasi atupun info jurusan Teknik Otomotif.

\section{METODE PENELITIAN}

Penelitian ini merupakan penelitian deskriptif. Untuk memperoleh data peneliti menggunakan angket yang disebarkan pada 138 orang mahasiswa.

Angket berisi 15 buah pertanyaan seputar pemanfaatan internet, pengaksesan konten di internet dan pemanfaatan infrastuktur yang sudah ada di linkungan kampus Jurusan Teknik Otomotif UNP.

\section{HASIL DAN PEMBAHASAN}

Mahasiswa jurusan Teknik Otomotif pada semester Juli-Desember 2012 berjumlah lebih dari 300 orang, sebagai responden diambil sampel 138 orang yang disurvei.

Angket yang telah dikembalikan oleh responden kemudian diolah dan dianalisa. Setelah itu didapatkan beberapa gambaran umum sebagai berikut:

Frekuensi Pemanfaatan Internet Oleh Mahasiswa

Frekuensi penggunaan jaringan hotspot wifi kampus oleh mahasiswa berbedabeda, ada yang hanya 1 kali dalam seminggu, 2-4 kali dalam seminggu dan setiap hari. Untuk lebih jelasnya bisa dilihat pada gambar 1 


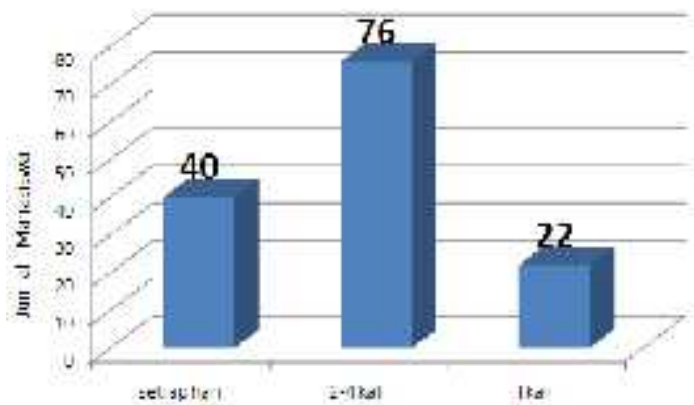

Gambar 1. Grafik Frekuensi pemanfaatan internet oleh mahasiswa

Dari gambar 1 dapat dilihat bahwa frekuensi penggunaan hotspot wifi tertinggi adalah pada 2-4 kali per minggu dengan jumlah mahasiswa 76 mahasiswa atau $55 \%$ dari jumlah seluruh responden. Untuk frekuensi penggunaan setiap hari yaitu pada tingkat menengah dengan 40 mahasiswa atau $29 \%$ dari jumlah responden dan sisanya mengaku hanya memanfaatkan hotspot wifi sekali dalam seminggu. Dilihat dari data tersebut, maka pemanfaatan hotspot wifi jurusan Teknik Otomotif berada pada tingkat yang cukup tinggi.

Tujuan Pemanfaatan Jaringan Internet $\mathrm{WiFi}$

Tujuan pemanfaatan jaringan internet WiFi (hotspot) oleh mahasiswa bermacam-macam, diantaranya untuk mencari materi kuliah sebagai referensi bahan belajar, mengunduh file dan software atau sekedar bermain game online.

Dalam pertanyaan ini satu orang diperbolehkan memberikan lebihdari satu jawaban. Penggambaran yang lebih jelas mengenai tujuan penggunaan hotspot wifi dapat dilihat pada gambar 2 . Data menunjukkan bahwa tingkat pemanfaatan hotspot wifi oleh mahasiswa cukup bervariasi.

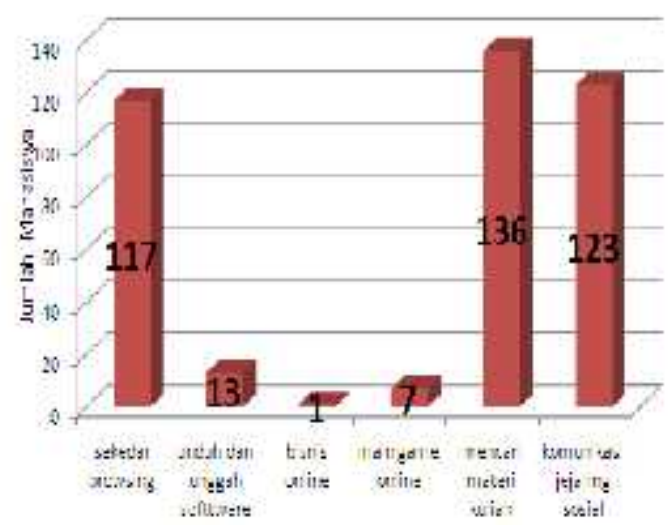

Gambar 2. Grafik Tujuan Penggunaan Hotspot Wifi Mahasiswa Jurusan Teknik Otomotif

Sebanyak 117 mahasiswa jurusan Teknik Otomotif atau 84,5\% dari jumlah responden menyatakan menggunakan hotspot wifi untuk sekedar browsing di internet. Ada 13 mahasiswa atau 9,5\% mengaku memanfaatkan hotspot wifi untuk unduh dan unggah software, sebanyak 1 mahasiwa atau $0,7 \%$ mengaku memanfaatkan hotspot wifi untuk bisnis online, dan terdapat 7 mahasiswa atau 5,3\% menyatakan memanfaatkan hotspot wifi untuk bermain game online. Selain itu, juga terdapat 136 mahasiswa atau $99 \%$ dari jumlah seluruh responden menyatakan memanfaatkan hotspot wifi untuk mencari materi kuliah sebagai tambahan referensi belajar. kemudian sebanyak 123 mahasiswa atau $89 \%$ menyatakan menggunakan hotspot wifi untuk komunikasi pada jejaring sosial seperti facebook dan twitter.

Seluruh data tersebut mencerminkan bahwa pemanfaatan hotspot wifi paling banyak untuk tujuan yang bersifat akademis, dalam hal ini untuk mencari materi perkuliahan.

$\begin{array}{lll}\text { Pemanfaatan } & \text { Sistem } & \text { Informasi } \\ \text { Akademik (SIA) } & \end{array}$

Sejauh ini, situs resmi kampus Universitas Negeri Padang yang paling sering dikunjungi adalah portal akademik. Pada dasarnya portal 
akademik digunakan untuk melihat Lembar Hasil Studi (LHS), mengisi Kartu Rencana Studi (KRS), mengunduh transkrip nilai, melihat pengumuman terbaru dari kampus, serta berkomunikasi antara dosen dengan mahasiswa dan juga komunikasi mahasiswa dengan mahasiswa dengan menggunakan layanan pesan dan forum diskusi.

Layanan yang diberikan cukup banyak, tetapi ternyata tidak semua layanan dimanfaatkan dengan baik oleh mahasiswa.

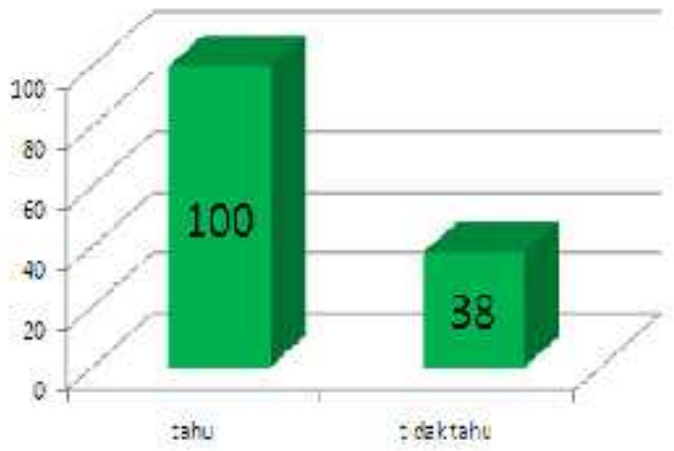

Gambar 3. Grafik jumlah mahasiswa yang tahu tentang semua layanan yang ada di SIA

Gambar 3 menunjukkan ada 38 mahasiswa yang tidak tahu tentang semua layanan SIA. Namun meski ada 100 orang yang tahu tentang layanan SIA ternyata hanya ada 9 orang (gambar 4) yang pernah menggunakan SIA untuk berkirim pesan.

Hal ini sangat disayangkan mengingat banyaknya fasilitas yang ada di SIA yang belum dimanfaatkan secara maksimal oleh mahasiswa.

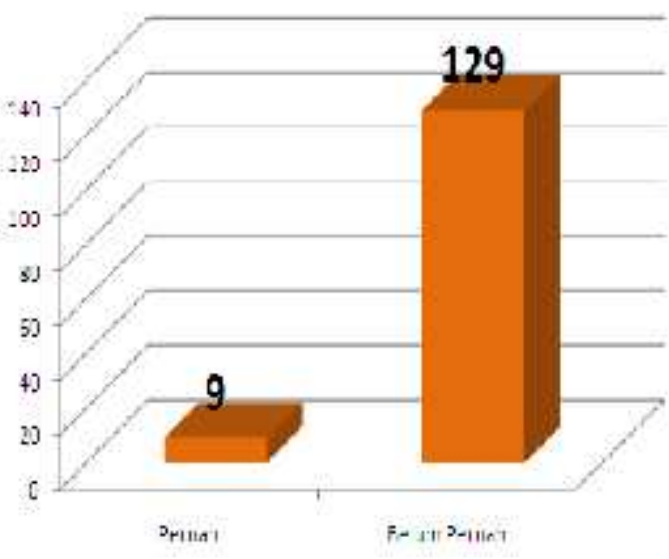

Gambar 4. Grafik jumlah mahasiswa yang pernah memanfaatkan SIA sebagai media diskusi dan berkirim pesan

Pengetahuan Mahasiswa Tentang Ketersediaan Informasi JTO di Internet

Tingkat pengetahuan mahasiswa jurusan Teknik Otomotif mengenai adanya informasi seputar otomotif juga masih bervariasi, sebagian besar mahasiswa malah tidak mengetahuinya, untuk lebih jelasnya dapat dilihat pada grafik yang ada di gambar 5 .

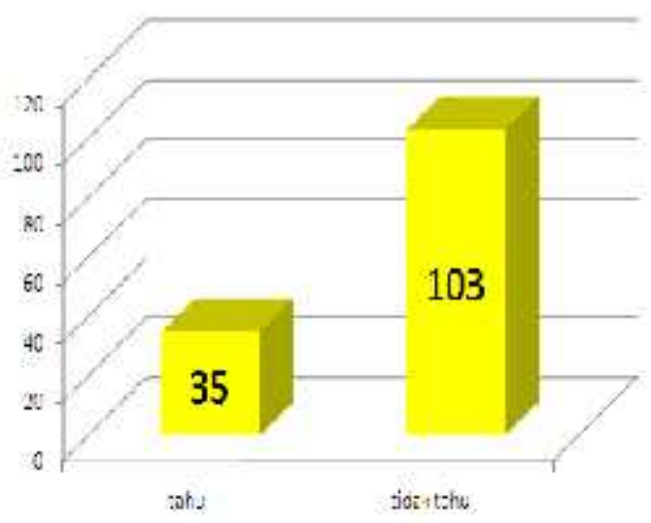

Gambar 5. Grafik Tingkat Pengetahuan Mahasiswa Mengenai Informasi Jurusan Teknik Otomotif di Internet

Berdasarkan data pada gambar 5, tingkat pengetahuan mahasiswa jurusan Teknik Otomotif mengenai ketersediaan informasi Jurusan Teknik Otomotif UNP di internet juga masih rendah, yaitu hanya 35 mahasiswa atau $25 \%$ yang menyatakan tahu, dan sisanya menyatakan tidak tahu. 
Aktivitas Internet Mahasiswa dalam BerJejaring Sosial

Pemanfaatan hotspot wifi yang telah ada selain untuk memenuhi kebutuhan yang bersifat akademis, juga digunakan oleh mahasiswa untuk keperluan lain yang lebih bersifat hiburan, sepeti bermain game online dan komunikasi melalui jejaring sosial seperti yang ditunjukkan pada gambar 2 .

Khusus untuk komunikasi jejaring sosial, dari hasil wawancara menunjukkan sebanyak 123 mahasiswa atau $89 \%$ dari jumlah responden menyatakan memanfaatkan hotspot wifi untuk berkomunikasi menggunakan jejaring sosial online seperti facebook dan twitter. Hal ini mengindikasikan bahwa kecenderungan penggunaan internet dalam kehidupan sehari-hari mahasiswa sangat tinggi.

\section{KESIMPULAN}

Frekuensi penggunaan fasilitas hotspot wifi jurusan teknik otomotif terhitung sangat tinggi dengan persentase hingga $84 \%$ dari seluruh responden yang mengaku menggunakan hotspot wifi lebih dari dua hari dalam seminggu.

Mahasiswa Jurusan Teknik Otomotif telah banyak menggunakan jaringan internet untuk memperkaya materi perkuliahan. Selain itu mereka juga banyak menggunakannya untuk ber-jejaring sosial.

Layanan pada Sistem Informasi Akademik yang ada belum dapat dimaksimalkan oleh Mahasiswa Jurusan Teknik Otomotif. Termasuk pengetahuan mahasiswa tentang ketersediaan informasi online tentang Jurusan Teknik Otomotif UNP juga sangat kurang.
Perlu dikembangkan sebuah sistem informasi khusus tengan Jurusan Teknik Otomotif UNP di internet misalnya dapat berupa website jurusan dan atau akun resmi di jejaring sosial.

\section{DAFTAR PUSTAKA}

Santoso Gempur. 2005. Metodologi Penelitian Kuantitatif \& kuanlitatif. Jakarta:Prestasi Pustaka Publisher.

Sutabri Tata. 2004. Analisa Sistem Informasi. Yogyakarta: Andi Publisher

Tim. Panduan Penggunaan SIA UNP, Padang : UPT-Puskom UNP.

\section{SARAN}

